\title{
Determination of moxifloxacin hydrochloride in AVELOX pharmacological formulations using modified potentiometer sensors
}

\author{
Sachin Kumar ${ }^{1), *}$ (оRсіD ID: 0000-0002-9131-582X), Sushil K. Sindhu' ${ }^{1)}$ (0000-0001-7944-8593), \\ Praveen Kumar') $^{1)}(0000-0002-7219-9958)$, Amit Sharma ${ }^{2)}$ (0000-0002-2878-1908), Suresh Sagadevan ${ }^{3), ~ *)}(0000-0003-0393-7344)$
}

DOI: dx.doi.org/10.14314/polimery.2021.11.4

\begin{abstract}
Three different electrodes modified with carbon paste (CP), silk-screen (SP) and poly(vinyl chloride) (PVC) were obtained to verify the reliability of AVELOX, the generic name of which is Moxifloxacin HCL (AV-MOXH). The sensing membranes were containing AVELOX ion associated complexes with sodium tetraphenylborate (NaTPB), phosphomolybdic acid (PMA), phosphotungstic acid (PTA), and ammonium reineckate ( $\mathrm{RN})$ as electroactive materials. All three electrodes gave fast, viable, and near-Nernstian linear responses over a relative wide concentration range that ranged from $1.0 \cdot 10^{-6}$ to $1.0 \cdot 10^{-2} \mathrm{~mol} / \mathrm{l} \mathrm{AV}-\mathrm{MOXH}$ at $25^{\circ} \mathrm{C}$ with a monovalent cationic decrease. The sensors demonstrated a good discernment of $\mathrm{AV}-\mathrm{MOXH}$ from numerous inorganic and organic compounds such as glucose, sucrose, $\mathrm{Na}^{+}, \mathrm{Ca}^{2+}$, etc. Additionally, the isothermal coefficients along with selectivity coefficients were calculated. The modified Screen Printed Electrode sensor appeared to be highly sensitive for the determination of AV-MOXH. The electrode response was observed in $\mathrm{pH}$ range 2-6 for ISPE electrodes and IPVC electrodes and 3-7 for ICPE electrodes under various temperature conditions. The short response time, lifetime validity, recovery, and all the methods of validation such as limit of detection and limit of quantification were estimated. The potentiometric method turned out to be suitable for determining AV-MOXH in pharmacological formulations, and the findings obtained are comparable to the "HPLC official method" in terms of the agreement. As a result, the postulated potentiometric approach was verified in accordance with IUPAC guidelines.
\end{abstract}

Keywords: AVELOX, moxifloxacin HCL, ion-selective electrodes, sodium tetraphenylborate, phosphomolybdic acid, phosphotungstic acid, poly(vinyl chloride), potentiometry.

\section{Oznaczanie chlorowodorku moksyfloksacyny w formulacjach farmakologicznych AVELOX przy użyciu zmodyfikowanych czujników potencjometrycznych}

Streszczenie: Otrzymano trzy różne elektrody modyfikowane pastą węglową (CP), sitodrukiem (SP) i polichlorkiem winylu (PVC) w celu oceny skuteczności działania leku AVELOX (nazwa rodzajowa Moxifloxacin HCL, AV-MOXH). Membrany czujników zawierały kompleksy jonu AVELOX z tetrafenyloboranem sodu (NaTPB), kwasem fosfomolibdenowym (PMA), kwasem fosfowolframowym (PTA) i soli Reineckego (RN) jako materiałami elektroaktywnymi. Wszystkie trzy elektrody dały szybkie i bliskie zależności liniowe Nernsta w zakresie stężeń AV-MOXH od 1.0·10-6 do $1.0 \cdot 10^{-2} \mathrm{~mol} / 1$ ( $\mathrm{w} 25^{\circ} \mathrm{C}$ ). Elektrody wykazały dobrą selektywność w oznaczaniu AV-MOXH względem wielu jonów i związków organicznych i nieorganicznych, jak glukoza, sacharoza, $\mathrm{Na}^{+}, \mathrm{Ca}^{2+}$ itp. Dodatkowo obliczono współczynniki izotermiczne oraz współczynniki selektywności. Zmodyfikowany czujnik z elektrodą sitodrukową okazał się być bardzo czuły do oznaczania AV-MOXH. Badania prowadzono w zakresie $\mathrm{pH} 2-6 \mathrm{w}$ przypadku elektrod ISPE i IPVC oraz 3-7 w przypadku elektrod ICPE w różnych temperaturach. Oszacowano czas odpowiedzi elektrod, ich czas życia, możliwość regeneracji, odzysk oraz granicę wykrywalności i granicę oznaczalności. Metoda potencjometryczna okazała się być odpowiednia do oznaczania AV-MOXH

\footnotetext{
1) Department of Chemistry, S.S.V.P.G. College (Affiliated to C.C.S. University Meerut, Meerut), Hapur-245101, India.

2) Department of Applied Sciences and Humanities, Raj Kumar Goel Institute of Technology 5KM Stone Delhi-Meerut Road, Ghaziabad-201003, India.

3) Nanotechnology \& Catalysis Research Centre, University of Malaya, Kuala Lumpur 50603, Malaysia.

*) Authors for correspondence: singhsachin001990@gmail.com, drsureshnano@gmail.com
} 
w preparatach farmakologicznych, a uzyskane wyniki są porównywalne z „oficjalną metodą HPLC”.

Słowa kluczowe: AVELOX, moksyfloksacyna HCL, elektrody jonoselektywne, tetrafenyloboran sodu, kwas fosfomolibdenowy, kwas fosfowolframowy, poli(chlorek winylu), potencjometria.

Moxifloxacin hydrochloride is the generic name of the drug AVELOX. AVELOX (Fig. 1) is a fluoroquinolone, a synthetic antibacterial drug that can be taken orally or intravenously. The monohydrochloride salt of 1-cyclopropyl-7-[(S,S)-2,8-diazabicyclo[4.3.0]non-8-yl]-6-fluoro-8-methoxy-1,4-dihydro-4-oxo-3-quinoline carboxylic acid is accessible as moxifloxacin, a fluoroquinolone used for treatment of pneumonia and respiratory tract infectious diseases. Moxifloxacin is well absorbed from the gastrointestinal system, with a $90 \%$ absolute bioavailability. It binds to serum proteins $30-50 \%$ of the time, regardless of drug dose, and is broadly dispersed throughout the body, with tissue concentrations frequently exceeding plasma concentrations [1]. It has molecular weight of 437.9 and is somewhat yellow crystalline in appearance. Its empirical formula is $\mathrm{C}_{21} \mathrm{H}_{24} \mathrm{FN}_{30}$. Microcrystalline cellulose (wood pulp), lactose monohydrate (the sugar found in milk), sodium croscarmellose (sodium carboxymethylcellulose or sodium CMC), magnesium stearate, hypromellose (hydroxypropyl methylcellulose, $\mathrm{C}_{56} \mathrm{H}_{108} \mathrm{O}_{30}$ ), titanium dioxide $\left(\mathrm{TiO}_{2}\right)$, polyethylene glycol $\left(\mathrm{C}_{2 \mathrm{n}} \mathrm{H}_{2 \mathrm{n}+2} \mathrm{O}_{\mathrm{n}+1}\right)$, and ferric oxide $\left(\mathrm{Fe}_{2} \mathrm{O}_{3}\right)$ are among the inactive constituents in AVELOX [2].

Adults can get community-acquired pneumonia caused by susceptible strains of Streptococcus pneumoniae (including MDRSP), Haemophilus influenzae, Moraxella catarrhalis, methicillin-resistant Staphylococcus aureus as well as Klebsiella, Mycoplasma and Chlamydophila. MDRSP isolates are resistant to penicillin, which minimum inhibitory concentration (MIC) at which the chemical the bacterial growth will stop is $2 \mu \mathrm{g} / \mathrm{ml}$, and $2^{\text {nd }}$ generation cephalosporins (for example cefuroxime), macrolides, tetracyclines, and trimethoprim/sulfamethoxazole. They're also

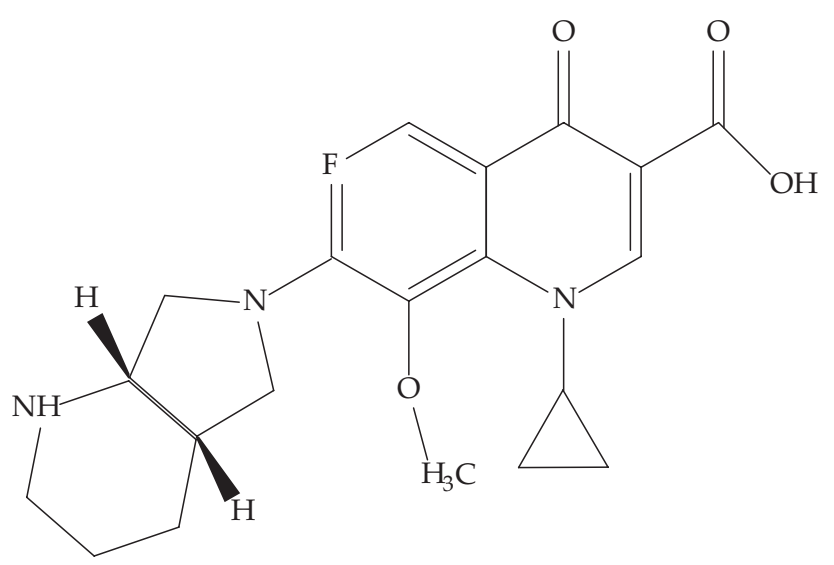

Fig. 1. Chemical structure of AVELOX (moxifloxacin hydrochloride) used to treat simple skin infections caused by bacteria like methicillin-resistant Staphylococcus aureus or Streptococcus pyogenes, Staphylococcus aureus, Escherichia coli [3], Klebsiella pneumoniae, or Enterobacter cloacae. Abscesses caused by sensitive isolates of E. coli, Bacteroides fragilis, Streptococcus anginosus, Streptococcus constellatus, Enterococcus faecalis, Proteus mirabilis, Clostridium perfringens, Bacteroides thetaiotaomicron, or Peptostreptococcus can be cured with AVELOX [4], which can be also used in the treatment of outbreaks such as pneumonic and septicemic plague, but only in cases of present sensitive Yersinia pestis isolatest, and in the prophylaxis of plague in humans. For practical reasons, moxifloxacin efficacy investigations on humans with plague were not possible. As a result, this recommendation is based only on animal efficacy trial [5]. AVELOX should be only used for preventing infections caused by susceptible bacteria that have been proven or strongly suspected, in order to prevent the formation of drug-resistant microbacteria and sustain the efficacy of AVELOX and other antibacterial drugs [6]. As far as culture and susceptibility data are available, they should be used to guide antibacterial therapy selection and modification. Local epidemiology and vulnerability patterns may help with speculative therapy selection in the absence of such data. AVELOX is taken once every 24 hours at a dose of $400 \mathrm{mg}$ (orally or as an intravenous infusion) [7].

A biological test for detecting moxifloxacin in tablets was published by Guerra et al. [8]. Various methods for determining and analyzing these types of tablets have been mentioned in the literature, including spectrophotometry [9, 10], spectrofluorimetry [11], electroanalysis [12], atomic absorption spectrometry (AAS) [13], conductometry [14], voltammetry [15, 16], high performance liquid chromatography in ultraviolet (HPLC-UV) [17-20], HPLC-fluorescence (HPLC-Fl) [21], capillary electrophoresis (CE) and HPLC-mass spectrometry (HPLC-MS) [22], ultra-performance liquid chromatography (UPLC) [23], liquid chromatography-mass spectrometry (LC-MS) [24, 25] and capillary zone electrophoresis [26] approaches for detecting moxifloxacin (MOX) alone and in conjunction with other medicines in various formulations and biological materials. Conversely, the majority of these approaches entail lengthy procedures, derivatization, and/or the use of sophisticated instruments. Because AVELOX-Monofloxacin HCL (AV-MOXH) is such an important pharmacological and analytical chemical, there has been an increase of interest in developing precise analytical methods for the quantification of AV-MOXH in samples of biological and pharmacological substances in recent years. Because of 
its great efficiency, selectivity, reproducibility, and sensitivity, HPLC is the most widely used analytical technique for medication quality control. Furthermore, in order to conserve the environment, the current tendency is to develop simple, quick, and environmentally friendly analytical methods [27]. The potentiometric analysis relies on estimating the comparative potential difference between both the sensor surface and the buffer solution, which gives data on the taster composition when no flow of current exists amongst them and the sample is not disrupted and remains unaffected [28]. Potentiometers, unlike other analytical procedures, do not consume analytes, which makes them especially attractive when only a small total amount needs to be detected. Furthermore, the analytical signal is independent of the electrode surface area, making downsizing possible. Potentiometric sensors have many economic advantages, including ease of construction, tracking instrumentation, rapid implementation, the ability to use bright and vivid colors, good accuracy, wide linear ranges, and the ability to combine with Flow Injection Analysis (FIA) systems. Thus, they provide satisfactory selectivity for the medication in the existence of numerous therapeutic excipients [29]. The activity (concentration) of the analyte determines the potential of these electrodes. Carbon Paste Electrodes (ICPE) offer the advantages of being simple to prepare, having quick response, being easily renewable, inexpensive, and able to be connected to basic instruments. Their low perfunctory and physical steadiness, as well as degeneration in non-polar electrolytic solvents, which resulted in signal degradation, confined their application to the research lab only. A frequent technique is to adapt the principle from carbon paste electrodes to more vigorous sensors, such as thick sheets used in Screen Printed Electrodes (ISPE). The detection limit, linear range, selectivity, operational $\mathrm{pH}$, temperature, and pressure constraints, as well as the short lifespan due to discharge out of electroactive material, are all critical difficulties that emerge with all traditional Ion-Selective Electrodes (ISE). Thick film technology, on the other hand, comprises the screen printing process, which is particularly ideal for commercialization because of its uncomplicatedness, cheap in price, excellent consistent, and efficiency for enormous production [30-32].

The manufacture of the modified electrodes within altered carbon paste electrode, screen printing, PVC ion-selective electrodes for the detection of AVELOX-Moxifloxacin HCL tablets (AV-MOXH) is reported in the current work. Membranes used in our studies were combined with sodium tetraphenylborate (NaTPB), phosphomolybdic acid (PMA), phosphotungstic acid (PTA), and ammonium reineckate $(\mathrm{RN})$ as electroactive materials in the Monofloxacin HCL complex. Their characteristics slopes and analytical performance with the influence of varied plasticizers, ion-pairing agent content, $\mathrm{pH}$ range, temperature, and effect of the interfering cations have been investigated. All the electrodes were used to measure AV-MOXH in both pure and pharmaceutical preparations. Method validation parameters were improved in accordance with ICH recommendations.

\section{EXPERIMENTAL PART}

\section{Experimental techniques}

Laboratory potential measurements were made with the Orion $\mathrm{pH} / \mathrm{mv}$ meter, model 330, and AV-MOXH membrane sensors in combination with an $\mathrm{Ag} / \mathrm{AgCl}$ double-junction reference electrode (Orion $\mathrm{pH} / \mathrm{mv}$ meter, model 90-02) and several drug ion-selective electrodes. The examined medicine (AVELOX-MOXHCL) was investigated using a digital multi-meter coupled to a portable computer system and a Brand digital burette. The current study used homemade printing carbon ink to make modified and in situ modified carbon paste, screen printed, and PVC electrodes as potentiometric sensors, as well as comparing the performance characteristics of such electrodes in determining AV-MOXH in pure and pharmacological preparations.

\section{Materials}

All used chemicals and reagents were of high pure analytical reagent (AI) grade and double distilled water was all through the experiment. The AVELOX (moxifloxacin hydrochloride) $400 \mathrm{mg}$ tablet was obtained from the Bayer manufacturer. Relative high molecular weight poly(vinyl chloride) (PVC), synthetic graphite powder (1-2 $\mu \mathrm{m}$ in size), $o$-nitrophenyloctylether (o-NPOE), tricresylphosphate (TCP), dibutylphthalate (DBP), dioctylphthalate (DOP), dioctylsebacate (DOS), and tetrahydrofurane (THF) of purity $>99 \%$, were supplied from Merck. Ion-pairing agents such as sodium tetraphenylborate (NaTPB) and ammonium reineckate $\{\mathrm{RN}$, $\left.\mathrm{NH}_{4}\left[\mathrm{Cr}\left(\mathrm{NH}_{3}\right)_{2}(\mathrm{SCN})_{4}\right] \cdot \mathrm{H}_{2} \mathrm{O}\right\}$ were supplied from Fluka. Phosphotungstic acid (PTA, $\mathrm{H}_{3} \mathrm{PW}_{12} \mathrm{O}_{40}$ ) and phosphomolybdic acid ( $\mathrm{PMA}, \mathrm{H}_{3} \mathrm{PMo}_{12} \mathrm{O}_{40}$ ) were purchased from $\mathrm{BDH}$. Acetone, cyclohexanone and tetrahydrofuran were all purchased from Aldrich Company.

\section{Preparation of the operational electrodes}

\section{Screen printed electrodes (SPE)}

To create disposal SPE electrodes, a man-made screen printer was used. A network of 12 electrodes was screen printed over bendable X-ray film by squeezing primed conductive ink to permeate across pores of a screen stencil. There were three primary steps in the screen printing electrodes:

a) Selection of the screen template. A dense weight polyester fabric (I003M Sefar Pet 1000, mesh or pores count 36) was pre-tensioned to a $35 \times 45 \mathrm{~cm}^{2}$ hardwood 
edging. Steel sheet was pre-stressed to a new casing of steel for building stainless steel model, and grooves with identical electrode dimensions were used [31].

b) Making of graphite-ink suspension. The well-designed screen printed electrodes were produced by using homemade carbon ink combined with $2.5-20 \mathrm{mg}$ of ion-pairing agent (NaTPB, PMA, RN, or PTA) in TCP (900 $\mathrm{mg}$ ) and $3.0 \mathrm{~g}$ of $8-10 \%$ PVC solution. $2.5 \mathrm{~g}$ of carbon powder was mixed in a continuous motorized mixing process to obtain a homogenous ink. After absolute involvement of the ink components with the help of magnetic stirrer the produced ink was again sonicated for about 60 minutes to enhance the uniformity and remove water molecules completely [32].

c) Screen printed electrodes (SPE) printing. Sheet of polyester was rinsed with concentrated nitric acid $\left(\mathrm{HNO}_{3}\right)$ and eroded multiple times by distilled water before being scrubbed with commercially available cleaners. After the treatment sheet of polyester was utilized as a substrate that was unaffected by the critical temperature or ink solvent and could be break into pieces with a pair of scissors only.

Prepared graphite ink was dispensed on top of the produced pores and pressed into the network by using an 8 -inch squeegee which was held at a $60^{\circ}$ angle, while the mesh was kept away from the sheet of polyester. After that, the squeegee was again dragged back through the template, ensuring that the electrode templates were entirely loaded with ink suspension. In a single fast operation, the woody frame was hard-pressed downwards across the polyester sheet and the squeegee was pulled crossway to the template forcing the ink through the mesh and onto the polyester sheet. The electrodes were then printed onto the polyester sheet after the stencil frame was removed. The electrodes were dried at $60^{\circ} \mathrm{C}$ before slicing out of the substrate. After the completion of this printing process, the stencil was washed with a commercially available thinner solution to remove any extra ink from the template.

\section{Carbon paste electrodes (CPE)}

Carbon paste electrodes were made by mixing different volumes of ion-pairing agents (in the range $2.5-20 \mathrm{mg}$ ) with $2.5 \mathrm{mg}$ carbon powder and TCP $(100 \mathrm{ml})$ in an intimate manner. After that the blend was carefully mashed in the mortar to achieve homogeneity. The obtained paste was firmly filled in the electrode build through the opening [33-35]. The surface of produced carbon paste electrode was meticulously smoothed with a membrane filter and washed with double distilled water to get a new working surface.

\section{PVC electrodes}

The PVC membrane mixtures were obtained by dispersing the recognition element, activator, and polymeric matrix (PVC) in tetrahydrofurane until they created a clear transparent solution, and afterwards putting into a $10 \mathrm{~cm}$ diameter Petri dish and covering with filter paper. The evaporation of tetrahydrofurane at ambient conditions for about 24 hours resulted in a bendable membrane with a thickness of roughly $100 \mu \mathrm{m}$ is obtained. The original sheet was cut with the help of a cork borer and affixed to the edge of a plastic tube filled with $10^{-3} \mathrm{~mol} / \mathrm{l}$ drug solution and $0.1 \mathrm{~mol} / 1 \mathrm{KCl}$, as needed, to establish the potential of internal $\mathrm{Ag} / \mathrm{AgCl}$ wire. To understand the effect of the internal filling solution composition, researchers used different solutions of pure AV-MOXH $\left(10^{-4}\right.$ to $\left.10^{-2} \mathrm{~mol} / \mathrm{l}\right) \mathrm{cou}-$ pled with $\mathrm{KCl}(0.1 \mathrm{~mol} / \mathrm{l})$. The electrode potential response was unaffected by the filling solution structure apart from the intercept. A mixture of $10^{-3} \mathrm{~mol} / \mathrm{l} \mathrm{AV}-\mathrm{MOXH}$ and $0.1 \mathrm{~mol} / \mathrm{K} \mathrm{KCl}$ was utilized as an interior filling solution [36].

\section{Measurements of potentials}

The samples of examined solutions were mixed and kept at room temperature. The electromotive force (EMF) of the following electrochemical cell was used to test the sensor's responsiveness to AV-MOXH': AV-MCPE; ICPE, IPVC, or ISPE | $\mathrm{Ag}|\mathrm{AgCl}|$ standard $\mathrm{KCl} \mid$ sample solution I AV-MCPE; ICPE, IPVC, or ISPE electrodes. The EMF was shown as a logarithm function of the AV-MOXH concentration. Serial dilution of a $10^{-2} \mathrm{~mol} / \mathrm{l} \mathrm{AV}-\mathrm{MOXH}$ stock solution yielded dilute AV-MOXH solutions (ranging from 1.0·10-2 to $\left.1.0 \cdot 10^{-7} \mathrm{~mol} / \mathrm{l}\right)$. The detection limit was set at the intersection of the calibration curve's extrapolated linear sections.

\section{RESULTS AND DISCUSSION}

\section{Influence of the ion-pairing agent content with electrode potential}

Four ion-pairing agents, sodium tetraphenylborate (NaTPB), phosphomolybdic acid (PMA), phosphotungstic acid (PTA), and ammonium reineckate (RN) were deposited on three selected electrodes i.e. screen printed, carbon paste and polymatrix (PVC) electrodes. The amount of used ion-pairing agents was in the range of $2.5 \mathrm{mg}$ to $20 \mathrm{mg}$. The obtained results are shown in Fig. 2 and Table 1 (for ICPE electrodes containing NaTPB ion--pairing agent), Table 2 (for IPVC electrode with NaTPB, PMA, and PTA ion-pairing agents), and Table 3 (for ISPE electrodes with NaTPB, RN, and PTA ion-pairing agents). The slope values for IPVC electrodes with $7.5 \mathrm{mg}$ of ion-pairing agent were: $53.0 \pm 1.5 \mathrm{mV} / \mathrm{dec}$ (where $\mathrm{mV} / \mathrm{dec}$ stands for $\mathrm{mV}$ per concentration decade) for NaTPB, 58.2 $\pm 3.9 \mathrm{mV} / \mathrm{dec}$ for PMA, and $51.6 \pm 2.0 \mathrm{mV} / \mathrm{dec}$ for PTA. For ISPE modified electrodes the observed slope values were $59.7 \pm 2.0 \mathrm{mV} / \mathrm{dec}$ for $22 \mathrm{mg} \mathrm{NaTPB}$, $60.1 \pm 2.0 \mathrm{mV} / \mathrm{dec}$ for $16 \mathrm{mg} \mathrm{RN}$, and $58.9 \pm 3.2 \mathrm{mV} / \mathrm{dec}$ for $30 \mathrm{mg}$ PTA ion-pairing agents. The obtained slope value for ICPE electrode modified with $7.5 \mathrm{mg}$ NaTPB was $60.0 \pm 2.3 \mathrm{mV} / \mathrm{dec}$. 
a)

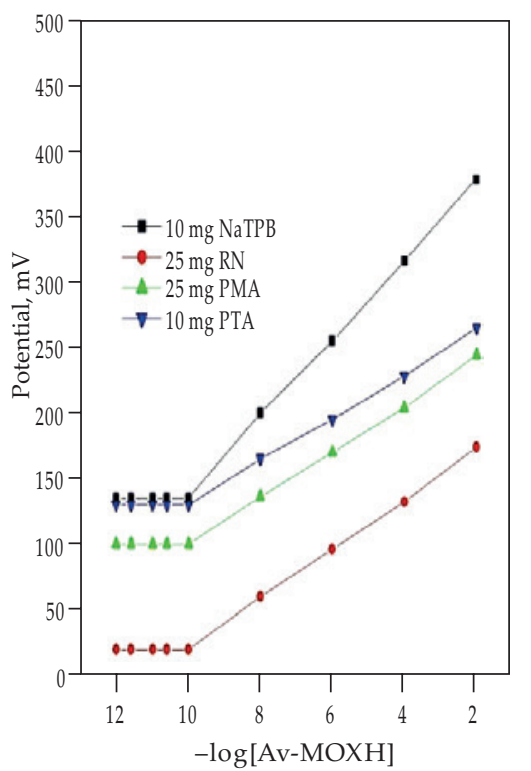

b)

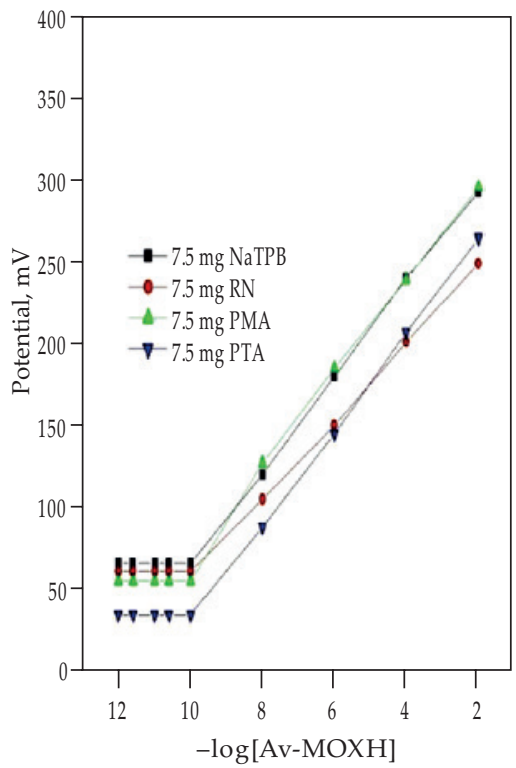

c)

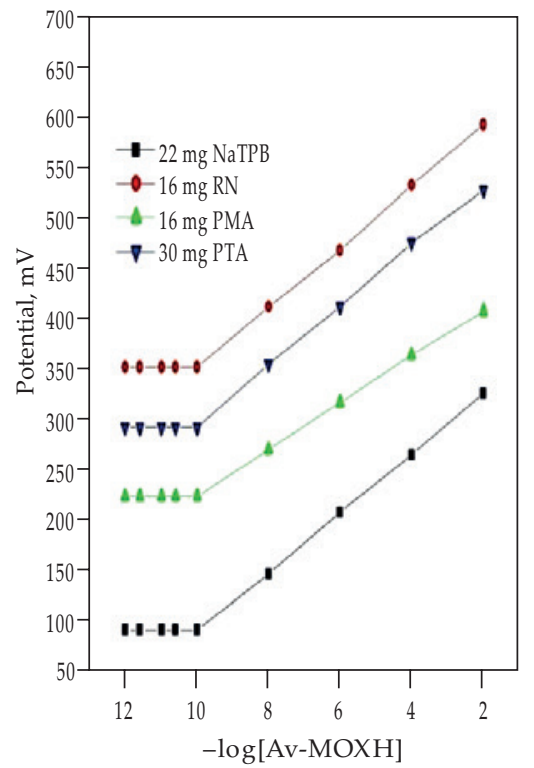

Fig. 2. Influence of selected ion-pairing agents on electrodes: a) ICPE, b) IPVC, c) ISPE

T a b l e 1. Slope values for ICPE electrodes modified with NaTPB ion-pairing agent

\begin{tabular}{c|c|c|c}
\hline NaTPB, mg & Concentration range, mol/l & Obtained slope, $\mathrm{mV} / \mathrm{dec}$ & $R$ \\
\hline 2.5 & $1.0 \cdot 10^{-6}-1.0 \cdot 10^{-2}$ & $71.0 \pm 1.8$ & 0.989 \\
5 & $1.0 \cdot 10^{-6}-1.0 \cdot 10^{-2}$ & $67.0 \pm 3.1$ & 0.998 \\
7.5 & $1.0 \cdot 10^{-6}-1.0 \cdot 10^{-2}$ & $60.0 \pm 2.3$ & 0.999 \\
10 & $1.0 \cdot 10^{-6}-1.0 \cdot 10^{-2}$ & $55.0 \pm 3.1$ & 0.999 \\
12.5 & $1.0 \cdot 10^{-6}-1.0 \cdot 10^{-2}$ & $50.0 \pm 1.0$ & 0.989 \\
15 & $1.0 \cdot 10^{-6}-1.0 \cdot 10^{-2}$ & $45.7 \pm 2.7$ & 0.999 \\
20 & $1.0 \cdot 10^{-6}-1.0 \cdot 10^{-2}$ & $40.5 \pm 2.4$ & 0.998 \\
\hline
\end{tabular}

T a b l e 2. Slope values for IPVC electrodes modified with NaTPB, RN, and PTA ion-pairing agents

\begin{tabular}{|c|c|c|c|c|}
\hline Ion-pairing agent & Concentration range, $\mathrm{mol} / \mathrm{l}$ & Content, mg & Slope, $\mathrm{mV} / \mathrm{dec}$ & $R$ \\
\hline \multirow{7}{*}{ Sodium tetraphenylborate (NaTPB) } & $1.0 \cdot 10^{-6}-1.0 \cdot 10^{-2}$ & 2.5 & $47.5 \pm 2.0$ & 0.999 \\
\hline & $1.0 \cdot 10^{-6}-1.0 \cdot 10^{-2}$ & 5 & $57.0 \pm 2.5$ & 0.989 \\
\hline & $1.0 \cdot 10^{-6}-1.0 \cdot 10^{-2}$ & 7.5 & $53.0 \pm 1.5$ & 0.999 \\
\hline & $1.0 \cdot 10^{-6}-1.0 \cdot 10^{-2}$ & 10 & $49.2 \pm 2.0$ & 0.998 \\
\hline & $1.0 \cdot 10^{-6}-1.0 \cdot 10^{-2}$ & 12.5 & $42.0 \pm 1.7$ & 0.999 \\
\hline & $1.0 \cdot 10^{-6}-1.0 \cdot 10^{-2}$ & 15 & $40.2 \pm 1.5$ & 0.999 \\
\hline & $1.0 \cdot 10^{-6}-1.0 \cdot 10^{-2}$ & 20 & $37.1 \pm 1.7$ & 0.999 \\
\hline \multirow{7}{*}{ Phosphomolybdic acid (PMA) } & $1.0 \cdot 10^{-6}-1.0 \cdot 10^{-2}$ & 2.5 & $52.0 \pm 1.7$ & 0.999 \\
\hline & $1.0 \cdot 10^{-6}-1.0 \cdot 10^{-2}$ & 5 & $59.7 \pm 3.5$ & 0.996 \\
\hline & $1.0 \cdot 10^{-6}-1.0 \cdot 10^{-2}$ & 7.5 & $58.2 \pm 3.9$ & 0.999 \\
\hline & $1.0 \cdot 10^{-6}-1.0 \cdot 10^{-2}$ & 10 & $50.0 \pm 2.8$ & 0.999 \\
\hline & $1.0 \cdot 10^{-6}-1.0 \cdot 10^{-2}$ & 12.5 & $53.0 \pm 0.2$ & 0.999 \\
\hline & $1.0 \cdot 10^{-6}-1.0 \cdot 10^{-2}$ & 15 & $49.0 \pm 2.3$ & 0.999 \\
\hline & $1.0 \cdot 10^{-6}-1.0 \cdot 10^{-2}$ & 20 & $51.0 \pm 2.7$ & 0.999 \\
\hline \multirow{7}{*}{ Phosphotungstic acid (PTA) } & $1.0 \cdot 10^{-6}-1.0 \cdot 10^{-2}$ & 2.5 & $53.0 \pm 1.8$ & 0.999 \\
\hline & $1.0 \cdot 10^{-6}-1.0 \cdot 10^{-2}$ & 5 & $55.7 \pm 2.5$ & 0.999 \\
\hline & $1.0 \cdot 10^{-6}-1.0 \cdot 10^{-2}$ & 7.5 & $51.6 \pm 2.0$ & 0.999 \\
\hline & $1.0 \cdot 10^{-6}-1.0 \cdot 10^{-2}$ & 10 & $45.0 \pm 2.5$ & 0.999 \\
\hline & $1.0 \cdot 10^{-6}-1.0 \cdot 10^{-2}$ & 12.5 & $45.0 \pm 2.5$ & 0.999 \\
\hline & $1.0 \cdot 10^{-6}-1.0 \cdot 10^{-2}$ & 15 & $43.1 \pm 1.7$ & 0.999 \\
\hline & $1.0 \cdot 10^{-6}-1.0 \cdot 10^{-2}$ & 20 & $40.1 \pm 2.1$ & 0.999 \\
\hline
\end{tabular}


T a b 1 e 3. Slope values for ISPE electrodes modified with NaTPB, RN, and PTA ion-pairing agents

\begin{tabular}{|c|c|c|c|c|}
\hline Ion-pairing agent & Concentration range, mol/1 & Content, mg & Slope, mV/dec & $R$ \\
\hline \multirow{7}{*}{ Sodium tetraphenylborate (NaTPB) } & $1.0 \cdot 10^{-6}-1.0 \cdot 10^{-2}$ & 2.5 & $38.0 \pm 0.8$ & 0.999 \\
\hline & $1.0 \cdot 10^{-6}-1.0 \cdot 10^{-2}$ & 5 & $40.2 \pm 1.9$ & 0.989 \\
\hline & $1.0 \cdot 10^{-6}-1.0 \cdot 10^{-2}$ & 7.5 & $50.0 \pm 2.5$ & 0.999 \\
\hline & $1.0 \cdot 10^{-6}-1.0 \cdot 10^{-2}$ & 10 & $54.3 \pm 3.0$ & 0.998 \\
\hline & $1.0 \cdot 10^{-6}-1.0 \cdot 10^{-2}$ & 12.5 & $56.6 \pm 1.7$ & 0.999 \\
\hline & $1.0 \cdot 10^{-6}-1.0 \cdot 10^{-2}$ & 15 & $59.7 \pm 2.0$ & 0.999 \\
\hline & $1.0 \cdot 10^{-6}-1.0 \cdot 10^{-2}$ & 20 & $52.5 \pm 3.2$ & 0.999 \\
\hline \multirow{5}{*}{ Ammonium reineckate $(\mathrm{RN})$} & $1.0 \cdot 10^{-6}-1.0 \cdot 10^{-2}$ & 6 & $35.3 \pm 1.8$ & 0.999 \\
\hline & $1.0 \cdot 10^{-6}-1.0 \cdot 10^{-2}$ & 12 & $40.7 \pm 2.5$ & 0.996 \\
\hline & $1.0 \cdot 10^{-6}-1.0 \cdot 10^{-2}$ & 16 & $60.1 \pm 2.0$ & 0.999 \\
\hline & $1.0 \cdot 10^{-6}-1.0 \cdot 10^{-2}$ & 24 & $50.0 \pm 2.3$ & 0.999 \\
\hline & $1.0 \cdot 10^{-6}-1.0 \cdot 10^{-2}$ & 30 & $45.5 \pm 3.0$ & 0.999 \\
\hline \multirow{6}{*}{ Phosphotungstic acid (PTA) } & $1.0 \cdot 10^{-6}-1.0 \cdot 10^{-2}$ & 8 & $20.1 \pm 0.7$ & 0.999 \\
\hline & $1.0 \cdot 10^{-6}-1.0 \cdot 10^{-2}$ & 12 & $41.4 \pm 1.6$ & 0.999 \\
\hline & $1.0 \cdot 10^{-6}-1.0 \cdot 10^{-2}$ & 16 & $45.0 \pm 1.8$ & 0.999 \\
\hline & $1.0 \cdot 10^{-6}-1.0 \cdot 10^{-2}$ & 24 & $52.8 \pm 2.7$ & 0.999 \\
\hline & $1.0 \cdot 10^{-6}-1.0 \cdot 10^{-2}$ & 30 & $58.9 \pm 3.2$ & 0.999 \\
\hline & $1.0 \cdot 10^{-6}-1.0 \cdot 10^{-2}$ & 35 & $52.8 \pm 1.6$ & 0.999 \\
\hline
\end{tabular}

\section{Influence of plasticizer on the characteristics of sensors}

A plasticizer is a compound that added to a material makes it milder and more stretchy and flexible, increases its elasticity, reduces viscosity, or reduces friction during manufacturing [37]. Plasticizers are often added to polymers like plastics and rubber, either to make the raw material easier to handle during fabrication or to fulfill the needs of the end product use [38]. Plasticizers have a considerable influence on the behavior of ion-selective electrodes (ISE). Because of the dissimilarity in their polarity physical features, the plasticizer increases their ionic mobility and sensing material solubility, and reduces the effect of bulk resistance of the electrode [39]. The use of a plasticizer aids in the screen printing process by preserving acceptable electrochemical properties. The performance of AV-MOXH ion-selective membrane sensors made of various electroactive materials was examined. Three reagents, NaTPB, PMA, and PTA, were used as ion-pairing reagents as potential conflicting ions for the production of the electroactive complex of AV-MOXH. Five different plasticizers, $o$-nitrophenyloctylether (o-NPOE), tricresylphosphate (TCP), dibutylphthalate (DBP), dioctylphthalate (DOP), and dioctylsebacate (DOS) were used over three electrodes (CPE, PVC, and SPE) to produce different combinations. The use of a plasticizer as fluidizer in the process of fabrication of PVC-based ISEs is well known, permitting homogeneous suspension and dispersion motion of the ion-pair in the structure of membrane [40]. The PVC membrane sensors of AV-MOXH with NaTPB, PMA, and PTA were revealed to be appro- priate and prime accessible intermediators with various plasticizers, like DBS, DOP, and $o$-NPOE. Compared to $o$-NPOE (58.2) and TCP (58.2) and some non-polar mediators such as DBS (slope $52.3 \mathrm{mV} / \mathrm{dec}$ ) and DOP (slope $50.7 \mathrm{mV} / \mathrm{dec}$ ) PVC membrane sensors offered low solubility of the ion-pair and feeble responses from the analyte. It appeared that $o$-NPOE enhanced membrane selectivity due to its high dielectrical constant, $\varepsilon=24$, which made significant changes in ion-association dissolution within the membrane only. As a result, partition coefficient was improved in the membrane. Plasticizers also delivered appropriate mechanical strength to the membrane when associated to poorer permittivity, for example in case of plasticizers such as DBS and DOP having permittivity 4 and 7, respectively, the solubility of electroactive materials was comparatively smaller than in case of $o$-NPOE. The effect of the plasticizers on the performance of ICPE electrode is shown in Table 4. o-Nitrophenyloctylether and tricresylphosphate revealed out to be the best plasticizers among all used at $10 \mathrm{mg}$ NaTPB.

T a b l e 4. Plasticizer effect on the performance of ICPE modified with $10 \mathrm{mg}$ NaTPB

\begin{tabular}{c|c|c}
\hline Type of plasticizer used & Slope, $\mathrm{mV} / \mathrm{dec}$ & $R$ \\
\hline o-NPOE & $58.2 \pm 1.3$ & 0.998 \\
TCP & $58.2 \pm 1.4$ & 0.999 \\
DBP & $52.3 \pm 1.6$ & 0.997 \\
DOS & $54.8 \pm 1.6$ & 0.997 \\
DOP & $50.7 \pm 1.7$ & 0.998 \\
\hline
\end{tabular}




\section{Analysis of isothermal coefficients}

The potentiometric response of the three electrodes (ICPE, IPVC, and ISPE) was found to be quite sensitive to changes in $\mathrm{pH}$ and temperature values. The isothermal coefficient of the electrode $\left(d E^{\circ} / d t\right)$ could be determined at different temperatures $\left(10,20,40,60,80\right.$, and $\left.90^{\circ} \mathrm{C}\right)$ with help of Nernst equation (Eq. 1). Because the equation relates (half or fully) a cell reaction reduction potential to a standard electrode potential that varies with temperature, changes in $\mathrm{pH}$ values are usually estimated by chemical species concentrations before reduction and oxidation. Thus, the standard electrode potential $\left(E^{\circ}\right)$ is determined by calibration in selected temperature compared to $(t-25)$ as the intercepts nearly at $\mathrm{p}[\mathrm{AV}-\mathrm{MOXH}]=0$, where $t$ is the temperature of the experiment according to the resulting equation 1 (Eq. 1) [41]. The isothermal coefficient of the three electrodes was represented by the slope of a straight line. The electrode potentials for the suggested sensor were determined in $\mathrm{pH}$ varying from 1 to 10 for concentration between $1 \cdot 10^{-2}$ and $1 \cdot 10^{-4} \mathrm{~mol} / \mathrm{l} \mathrm{AV}-\mathrm{MOXH}$ ionic solutions. The $\mathrm{pH}$ of tested solutions was attuned by the dropwise addition of $0.1 \mathrm{~mol} / 1$ hydrochloride acid. The measured isothermal coefficients are displayed in Table 5. The potential response of the ICPE electrodes was found to be constant $\sim 0.269 \mathrm{~V} /{ }^{\circ} \mathrm{C}$ in case of $10 \mathrm{mg}$ NaTPB ion modifier. Whereas, the potential response of IPVC was found to be $0.281,0.224$, and $0.279 \mathrm{~V} /{ }^{\circ} \mathrm{C}$ and constant at nearly $2-6 \mathrm{pH}$ range with $7.5 \mathrm{mg}$ TPB, PMA, and PTA ion modifier, respectively. Similarly, the potential response of ISPE electrodes was also found to be constant at nearly 2-6 pH range with three different modifiers (16 mg RN, $22 \mathrm{mg} \mathrm{NaTPB}$, and $30 \mathrm{mg}$ PTA) and its values were respectively $\sim 0.310, \sim 0.271$, and $\sim 0.292 \mathrm{~V} /{ }^{\circ} \mathrm{C}$. The experiments revealed that the electrodes comprised good thermal stability when used in a particular range of temperature and $\mathrm{pH}$. The selective electrodes were efficient at $60^{\circ} \mathrm{C}$ without making any significant changes in Nernstian equation.

$$
E_{\text {cell }}^{\circ}=E_{\text {cell }\left(25^{\circ} \mathrm{C}\right)}^{\circ}+\frac{d E_{\text {cell }}^{\circ}}{d t}+(t-25)
$$

$\mathrm{T}$ a b 1 e 5. Influence of $\mathrm{pH}$ on the isothermal coefficients of selected electrodes

\begin{tabular}{l|c|c|c}
\hline Electrode & Ion modifier & $\mathrm{pH}$ range & $\begin{array}{c}\text { Isothermal } \\
\text { coefficient } \\
\mathrm{V} /{ }^{\circ} \mathrm{C}\end{array}$ \\
\hline ICPE & $10 \mathrm{mg}$ NaTPB & $3.0-7.0$ & 0.269 \\
IPVC & $7.5 \mathrm{mg}$ TPB & $2.0-6.0$ & 0.281 \\
IPVC & $7.5 \mathrm{mg}$ PMA & $2.0-6.0$ & 0.224 \\
IPVC & $7.5 \mathrm{mg}$ PTA & $2.0-6.0$ & 0.279 \\
ISPE & $16 \mathrm{mg}$ RN & $2.0-6.0$ & 0.310 \\
ISPE & $22 \mathrm{mg}$ NaTPB & $2.0-6.0$ & 0.271 \\
ISPE & $30 \mathrm{mg}$ PTA & $2.0-6.0$ & 0.292 \\
\hline
\end{tabular}

\section{Potentiometer selectivity and interference ions study}

The equilibria at the intersection between the sample and the electrode membrane were quantitatively compared to the selectivity of solvent polymeric membrane ion-selective electrodes (ISE) [36] determined as potentiometric selectivity coefficient $\left(K_{\mathrm{A}, \mathrm{B}}^{\mathrm{pot}}\right)$. This selectivity coefficient refers to the ability of an ion-selective electrode to distinguish a specific primary ion from other present interfering ions $[42,43]$. This potentiometer selectivity behavior is the most important feature of a screen printed electrodes (SPE), carbon paste electrodes (CPE), and polymatrix (polymeric matrix) electrodes (PVC) sensors, revealing the possibility of accurate drug measurement. The potentiometric selectivity coefficients $\left(K_{\mathrm{A}, \mathrm{B}}^{\mathrm{pot}}\right)$ were calculated using two methods approved by the International Union of Pure and Applied Chemistry (IUPAC):

a) Separate Solution Method (SSM): for determining low selectivity coefficients that are highly time-dependent and, based on evidence, are a precise linear time-dependent elevated to a particular negative power.

b) Matched Potential Method (MPM): The motion ratio between primary ion and interfering ion that provides the equivalent change in potential as a reference solution is described as the matched potential method (MPM) utilized in the selectivity coefficient.

The Nernst equation responses to the movements of any primary or interfering ions are not obeyed by this potential approach [44]. Thus, MPM selectivity coefficient method is most suitable for the calculation of selectivity coefficients for neutral compounds. The selectivity coefficients $\left(\log K_{\mathrm{A}, \mathrm{B}}^{\mathrm{pot}}\right)$ of the three selected electrodes (ISPE, ICPE, and IPVC) were evaluated by applying a separate solution method (SSM) with some re-arranged Nicolsky equation (Eq. 2) [45-47].

$$
\log K_{\mathrm{A}, \mathrm{B}}^{\mathrm{pot}}=\left(\frac{E_{1}-E_{2}}{S}\right)+\left(1+\frac{Q_{1}}{Q_{2}}\right) \log a
$$

where: $E_{1}$ - potential measured in $1.0 \cdot 10^{-3} \mathrm{~mol} / \mathrm{l}$ AV-MOXH (A)

$E_{2}$ - potential measured in $1.0 \cdot 10^{-3} \mathrm{~mol} / 1$ of the interfering compound (B)

$Q_{1}$ - charge of the AV-MOXH (A)

$Q_{2}$ - charge of interfering species (B)

$S$ - slope of the electrode calibration plot.

The selectivity coefficients were calculated for selective electrode measured at $10 \mathrm{mg}$ NaTPB for ICPE ion-pairing agent. For IPVC ion-pairing agent the selectivity coefficients were determined with $7.5 \mathrm{mg}$ of NaTPB, PMA, and PTA. Whereas, ISPE electrodes ion-pairing selectivity coefficients were determined at $16 \mathrm{mg}$ RN, $22 \mathrm{mg} \mathrm{NaTPB}$, and $30 \mathrm{mg}$ PTA. The results obtained by using Eq. 2 are summarized in Table 6. No significant interference was observed with the reference ions and the exact selectivity of the test electrodes required for AV-MOXH is reflected. 
T a b 1 e 6 . Selectivity coefficients of ICPE, IPVC, and ISPE electrodes

\begin{tabular}{|c|c|c|c|c|c|c|c|c|}
\hline \multirow{2}{*}{ Method } & \multirow{2}{*}{$\begin{array}{l}\text { Interfering } \\
\text { ion }\end{array}$} & \multicolumn{7}{|c|}{ Selectivity coefficient $\left(K_{\mathrm{A}, \mathrm{B}}^{\mathrm{pot}}\right)$} \\
\hline & & $\begin{array}{c}\text { ICPE } \\
10 \mathrm{mg} \text { NaTPB }\end{array}$ & $\begin{array}{c}\text { IPVC } \\
7.5 \mathrm{mg} \text { NaTPB }\end{array}$ & $\begin{array}{c}\text { IPVC } \\
7.5 \text { mg PMA }\end{array}$ & $\begin{array}{c}\text { IPVC } \\
7.5 \mathrm{mg} \text { PTA }\end{array}$ & $\begin{array}{c}\text { ISPE } \\
22 \mathrm{mg} \mathrm{NaTPB}\end{array}$ & $\begin{array}{c}\text { ISPE } \\
30 \mathrm{mg} \text { PTA }\end{array}$ & $\begin{array}{c}\text { ISPE } \\
16 \mathrm{mg} \mathrm{RN}\end{array}$ \\
\hline \multirow{7}{*}{$\begin{array}{l}\text { Matched } \\
\text { Potential } \\
\text { Method } \\
\text { (MPM) }\end{array}$} & Glucose & $1.67 \cdot 10^{-4}$ & $5.10 \cdot 10^{-4}$ & $1.26 \cdot 10^{-4}$ & $9.36 \cdot 10^{-6}$ & $4.92 \cdot 10^{-4}$ & $8.33 \cdot 10^{-3}$ & $3.68 \cdot 10^{-3}$ \\
\hline & Fructose & $4.58 \cdot 10^{-4}$ & $7.08 \cdot 10^{-4}$ & $1.61 \cdot 10^{-4}$ & $4.64 \cdot 10^{-5}$ & $4.29 \cdot 10^{-4}$ & $7.38 \cdot 10^{-3}$ & $8.82 \cdot 10^{-3}$ \\
\hline & Maltose & $5.01 \cdot 10^{-4}$ & $3.83 \cdot 10^{-4}$ & $1.19 \cdot 10^{-4}$ & $5.44 \cdot 10^{-5}$ & $2.97 \cdot 10^{-4}$ & $5.86 \cdot 10^{-3}$ & $6.23 \cdot 10^{-3}$ \\
\hline & Lactose & $4.42 \cdot 10^{-4}$ & $8.37 \cdot 10^{-4}$ & $1.98 \cdot 10^{-4}$ & $4.43 \cdot 10^{-5}$ & $2.79 \cdot 10^{-4}$ & $5.65 \cdot 10^{-3}$ & $1.32 \cdot 10^{-3}$ \\
\hline & Sucrose & $3.60 \cdot 10^{-4}$ & $9.72 \cdot 10^{-4}$ & $2.81 \cdot 10^{-4}$ & $6.39 \cdot 10^{-5}$ & $8.92 \cdot 10^{-4}$ & $6.50 \cdot 10^{-3}$ & $3.29 \cdot 10^{-3}$ \\
\hline & Starch & $8.20 \cdot 10^{-5}$ & $2.26 \cdot 10^{-4}$ & $2.19 \cdot 10^{-4}$ & $4.92 \cdot 10^{-6}$ & $8.26 \cdot 10^{-4}$ & $5.04 \cdot 10^{-3}$ & $2.96 \cdot 10^{-3}$ \\
\hline & Glycine & $1.32 \cdot 10^{-4}$ & $7.60 \cdot 10^{-4}$ & $3.99 \cdot 10^{-4}$ & $4.29 \cdot 10^{-5}$ & $9.61 \cdot 10^{-4}$ & $4.49 \cdot 10^{-3}$ & $7.68 \cdot 10^{-4}$ \\
\hline \multirow{13}{*}{$\begin{array}{c}\text { Separate } \\
\text { Solution } \\
\text { Method } \\
\text { (SSM) }\end{array}$} & $\mathrm{Na}^{+}$ & $5.61 \cdot 10^{-5}$ & $5.02 \cdot 10^{-6}$ & $5.96 \cdot 10^{-6}$ & $2.94 \cdot 10^{-6}$ & $4.17 \cdot 10^{-5}$ & $3.92 \cdot 10^{-5}$ & $8.88 \cdot 10^{-5}$ \\
\hline & $\mathrm{Cd}^{2+}$ & $2.77 \cdot 10^{-4}$ & $1.29 \cdot 10^{-4}$ & $1.67 \cdot 10^{-4}$ & $6.48 \cdot 10^{-5}$ & $2.72 \cdot 10^{-4}$ & $1.26 \cdot 10^{-3}$ & $9.81 \cdot 10^{-3}$ \\
\hline & $\mathrm{K}^{+}$ & $3.86 \cdot 10^{-5}$ & $3.91 \cdot 10^{-6}$ & $4.74 \cdot 10^{-6}$ & $1.87 \cdot 10^{-6}$ & $7.28 \cdot 10^{-5}$ & $5.66 \cdot 10^{-5}$ & $1.11 \cdot 10^{-4}$ \\
\hline & $\mathrm{Mg}^{2+}$ & $2.70 \cdot 10^{-4}$ & $1.14 \cdot 10^{-4}$ & $1.47 \cdot 10^{-4}$ & $4.77 \cdot 10^{-5}$ & $4.86 \cdot 10^{-3}$ & $1.60 \cdot 10^{-3}$ & $2.16 \cdot 10^{-3}$ \\
\hline & $\mathrm{Zn}^{2+}$ & $3.24 \cdot 10^{-4}$ & $1.45 \cdot 10^{-4}$ & $1.78 \cdot 10^{-4}$ & $6.75 \cdot 10^{-5}$ & $5.66 \cdot 10^{-3}$ & $7.05 \cdot 10^{-4}$ & $1.64 \cdot 10^{-3}$ \\
\hline & $\mathrm{Ni}^{2+}$ & $1.76 \cdot 10^{-4}$ & $1.50 \cdot 10^{-4}$ & $1.83 \cdot 10^{-4}$ & $8.53 \cdot 10^{-5}$ & $1.69 \cdot 10^{-3}$ & $8.52 \cdot 10^{-4}$ & $2.44 \cdot 10^{-3}$ \\
\hline & $\mathrm{Mn}^{2+}$ & $2.92 \cdot 10^{-4}$ & $1.08 \cdot 10^{-4}$ & $1.30 \cdot 10^{-4}$ & $5.35 \cdot 10^{-5}$ & $1.95 \cdot 10^{-3}$ & $8.22 \cdot 10^{-4}$ & $3.42 \cdot 10^{-3}$ \\
\hline & $\mathrm{Ba}^{2+}$ & $2.12 \cdot 10^{-4}$ & $2.87 \cdot 10^{-4}$ & $2.00 \cdot 10^{-4}$ & $4.53 \cdot 10^{-5}$ & $2.52 \cdot 10^{-3}$ & $9.28 \cdot 10^{-4}$ & $2.24 \cdot 10^{-3}$ \\
\hline & $\mathrm{Fe}^{3+}$ & $1.23 \cdot 10^{-4}$ & $2.75 \cdot 10^{-4}$ & $3.65 \cdot 10^{-4}$ & $1.33 \cdot 10^{-4}$ & $1.24 \cdot 10^{-4}$ & $1.89 \cdot 10^{-4}$ & $1.42 \cdot 10^{-4}$ \\
\hline & $\mathrm{Pb}^{2+}$ & $1.16 \cdot 10^{-4}$ & $1.59 \cdot 10^{-4}$ & $1.54 \cdot 10^{-4}$ & $7.38 \cdot 10^{-5}$ & $2.41 \cdot 10^{-3}$ & $1.95 \cdot 10^{-4}$ & $1.22 \cdot 10^{-3}$ \\
\hline & $\mathrm{Al}^{3+}$ & $8.97 \cdot 10^{-4}$ & $1.97 \cdot 10^{-4}$ & $3.49 \cdot 10^{-4}$ & $1.83 \cdot 10^{-4}$ & $1.11 \cdot 10^{-4}$ & $1.53 \cdot 10^{-4}$ & $1.20 \cdot 10^{-4}$ \\
\hline & $\mathrm{Cr}^{3+}$ & $1.16 \cdot 10^{-4}$ & $2.73 \cdot 10^{-4}$ & $3.91 \cdot 10^{-4}$ & $3.39 \cdot 10^{-4}$ & $1.14 \cdot 10^{-4}$ & $1.33 \cdot 10^{-4}$ & $1.05 \cdot 10^{-4}$ \\
\hline & $\mathrm{Cu}^{2+}$ & $5.66 \cdot 10^{-5}$ & $7.31 \cdot 10^{-4}$ & $1.16 \cdot 10^{-4}$ & $7.93 \cdot 10^{-5}$ & $1.49 \cdot 10^{-3}$ & $2.38 \cdot 10^{-4}$ & $1.56 \cdot 10^{-3}$ \\
\hline
\end{tabular}

The results also revealed that there were no severe interference ions obtained in reaction with glucose, fructose, maltose, lactose, and starch with all three used electrodes. Inorganic cations, on the other hand, did not obstruct due to dissimilarities in ionic size, and therefore their interactions, polarization, and porosity and permeability when compared to those of the $\mathrm{AV}-\mathrm{MOXH}^{+}$cation.

\section{Analysis of the response time of the selective electrode}

Average reaction or response time is defined as the time it takes for the electrode to reach a stable potential within $1 \mathrm{mV}$ of the final equilibrium value [47]. The response

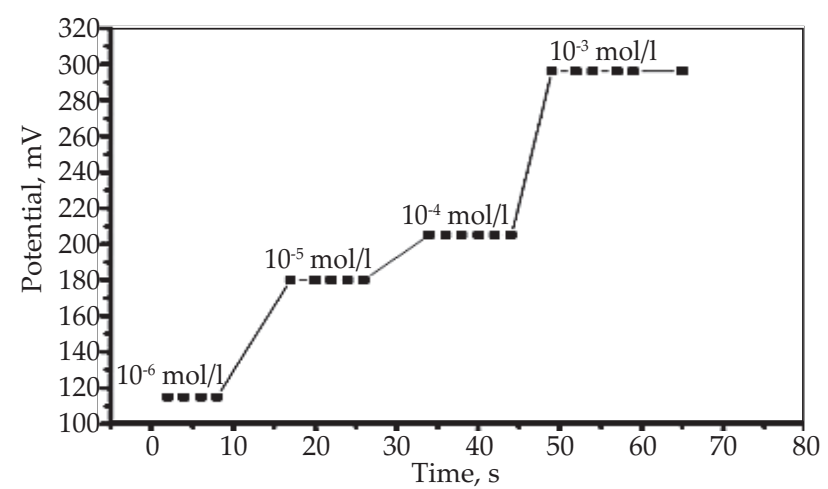

Fig. 3. Dynamic response time measured for ICPE electrode modified with $10 \mathrm{mg}$ NaTPB ion-pairing agent time is a significant aspect that characterizes ion-selective electrodes (ISE) measured in seconds. After sequential entanglements in a series of solutions, each with a 10 -fold concentration change, it could be well defined as the time it took the electrodes to reach stable potential values of about $90 \%$ of the final equilibrium values [48-51]. The sensor dynamic response time was measured for concentrations ranging from $1.0 \cdot 10^{-6}$ to $1.0 \cdot 10^{-3} \mathrm{~mol} / 1$ and results are given in Figs. $3-5$. For the ICPE modified with NaTPB ion-pairing agent (Fig. 3), the electrode response time was determined to be 7.23 seconds. For IPVC (Fig. 4), the response time was found to be $\sim 7.65$ seconds with NaTPB modifying agent, 7.02 seconds with RN modifying agent and 5.64 seconds. For the ISPE electrode (Fig. 5), the response time was 5.10 seconds with NaTPB, 5.32 seconds with RN, and 4.65 seconds with PTA modifying ion-pairing agents. The best electrodes among them having lower response time were screen printed electrodes.

\section{Lifetime measurement of sensors}

The lifetime of the three selected sensors (ICPE, IPVC, and ISPE) was investigated by systematically assembling the electrode calibration graphs under ideal circumstances for several days, as shown in Figs. 6-8. The lifetime was found to be approximately $\sim 49$ days in case of ICPE electrodes modified with NaTPB ion-pairing agent (Fig. 6). For IPVC (Fig. 7), the lifetime was found to be 
a)

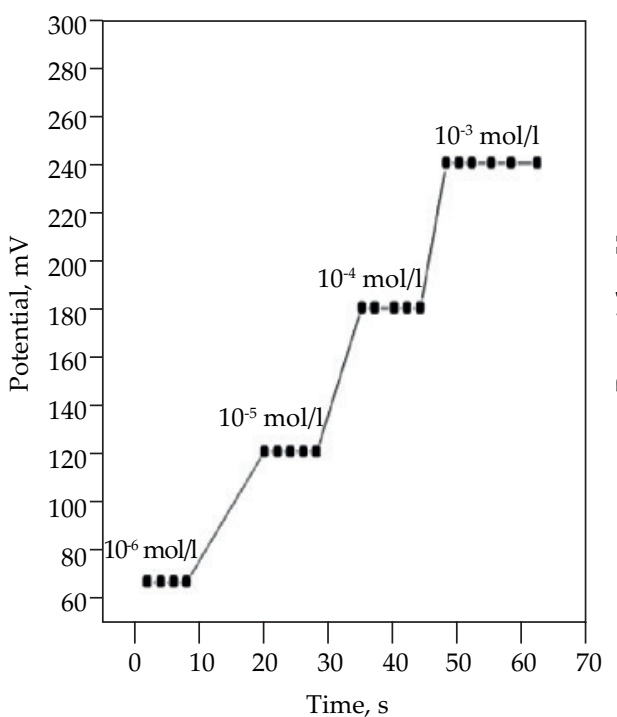

b)

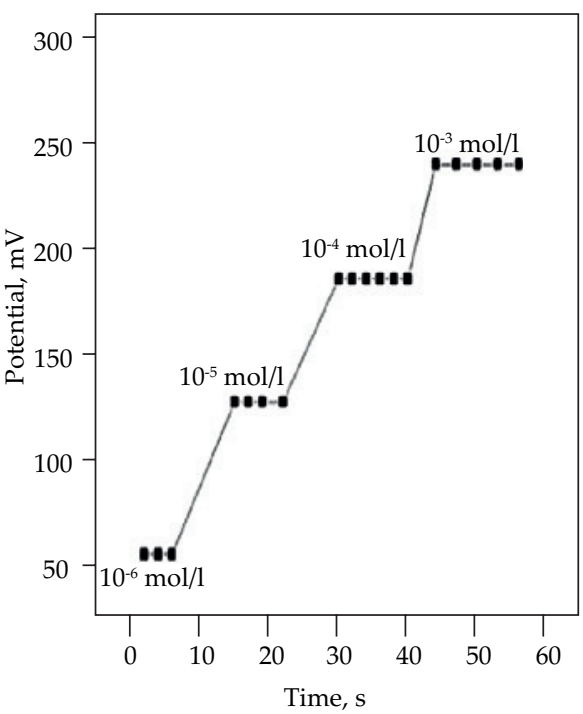

c)

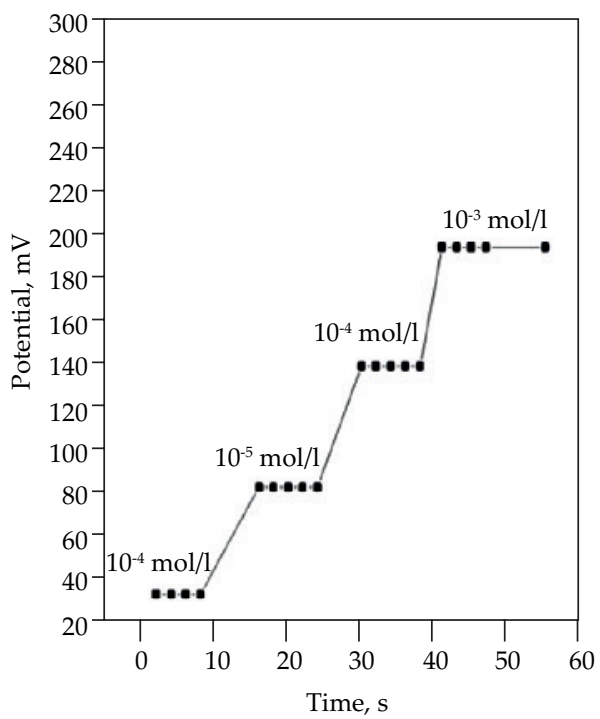

Fig. 4. Dynamic response time measured for IPVC electrode modified with 7.5 mg of: a) NaTPB, b) PMA, c) PTA ion-pairing agents

a)

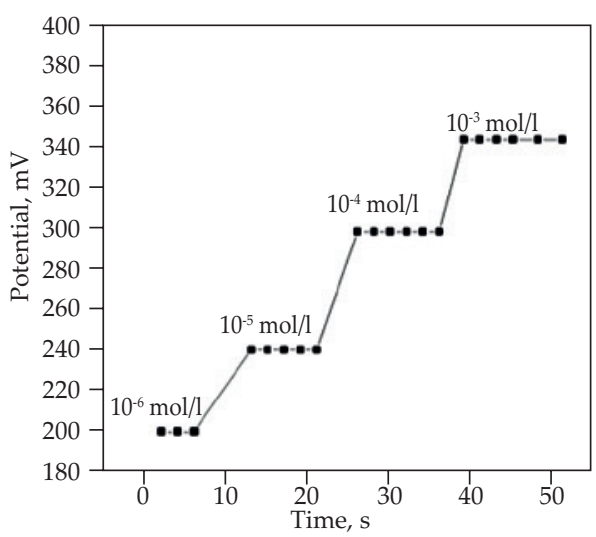

b)

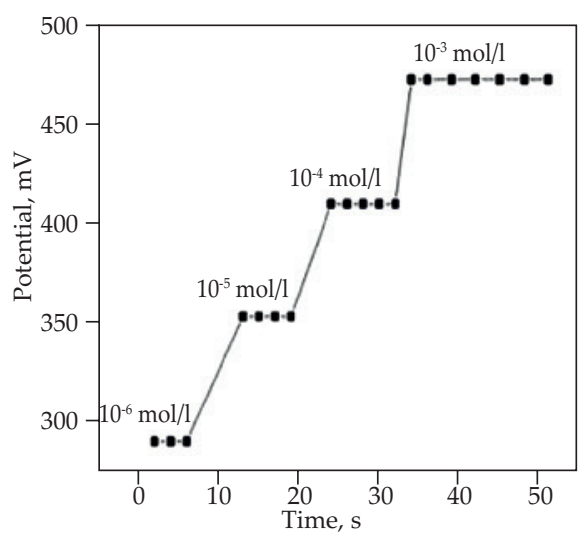

c)

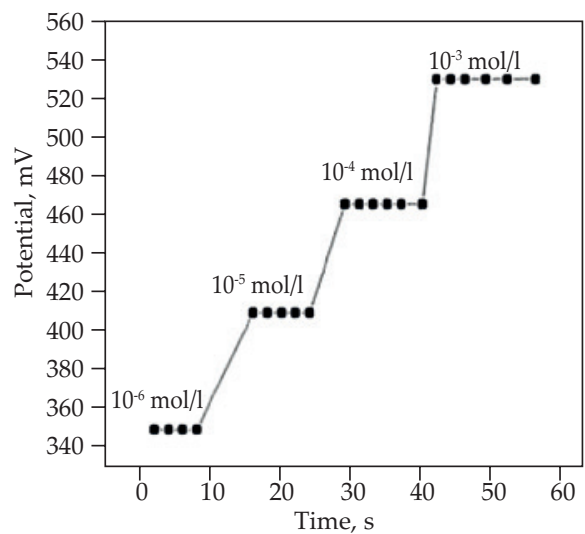

Fig. 5. Dynamic response time measured for ISPE electrode modified with: a) $22 \mathrm{mg} \mathrm{NaTPB}$, b) $30 \mathrm{mg}$ PTA, c) $16 \mathrm{mg}$ RN ion-pairing agents

approximately $\sim 16$ days with $7.5 \mathrm{mg}$ NaTPB, 18 days with $7.5 \mathrm{mg}$ PMA, and 17 days with $7.5 \mathrm{mg}$ PTA modifying ion-pairing agent. For ISPE electrodes (Fig. 8), the lifetime was estimated at nearly $\sim 80$ days with $22 \mathrm{mg}$ NaTPB, 90 days with $16 \mathrm{mg}$ RN, and 22 days with $30 \mathrm{mg}$ PTA modifying ion-pairing agents. No significant changes

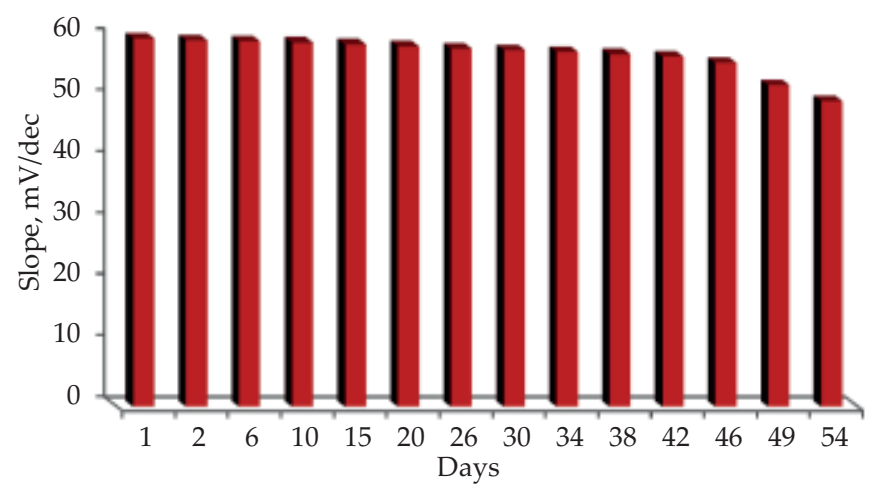

Fig. 6. Lifetime of ICPE modified with $10 \mathrm{mg}$ NaTPB ion-pairing agent were observed in slopes obtained from calibration graphs (Figs. 6-8). The slope of the calibration graph seemed to decline after the above mentioned period.

Squeezing off a little bit of the paste and polishing it on filter paper created a sparkling new surface every time a carbon paste electrode (CPE) was used for measurement. Before being employed in potentiometric tests, SPEs were produced and kept at $4^{\circ} \mathrm{C}$.

\section{Standard calculations, recovery and ruggedness analysis of sensors}

The suggested electrodes were used to determine the potency of the AV-MOXH medication in formulations that are both pristine and potentiometric treatment. Data acquired are summarized in Table 7 and the outcomes were compared to the HPLC official technique. The recoveries of AV-MOXH were examined by associating the potential of the measured or detected concentration to a directly added standard in tris buffer whose $\mathrm{pH}$ 
a)

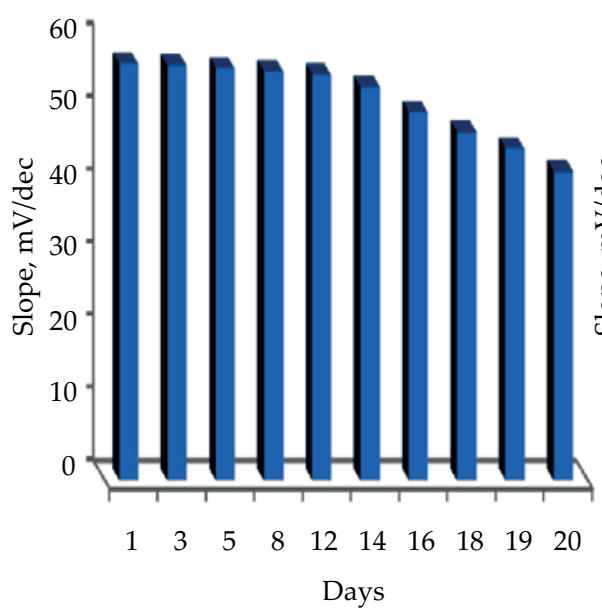

b)

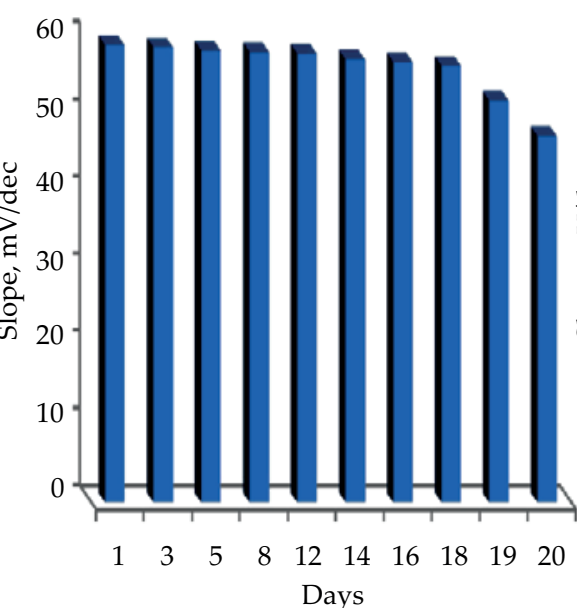

c)

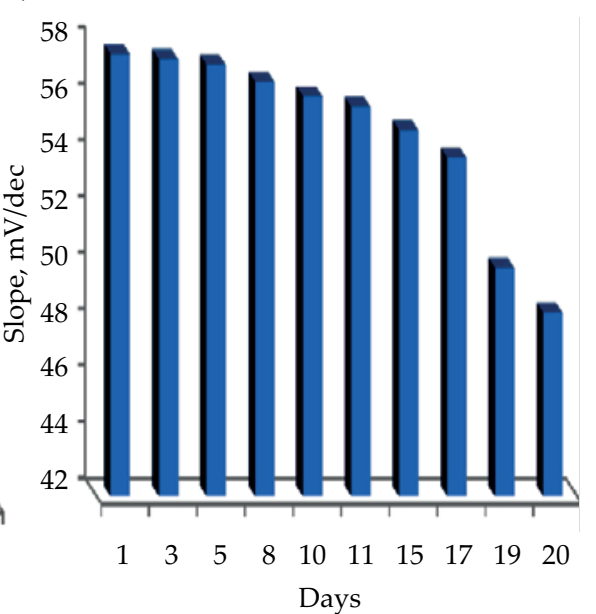

Fig. 7. Lifetime of IPVC modified with $7.5 \mathrm{mg}$ of: a) NaTPB, b) PMA, c) PTA ion-pairing agents

a)

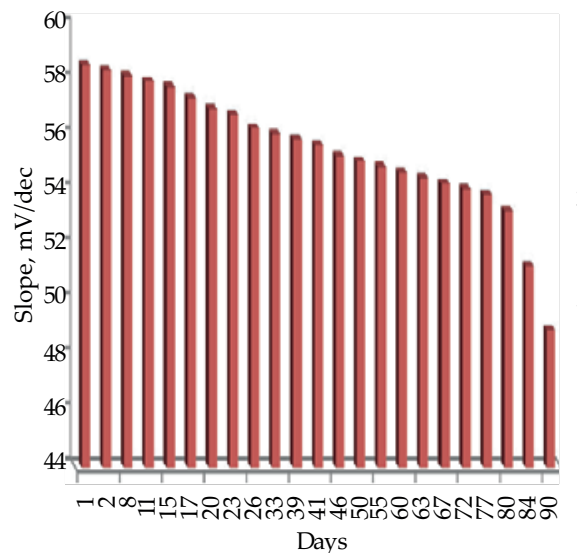

b)

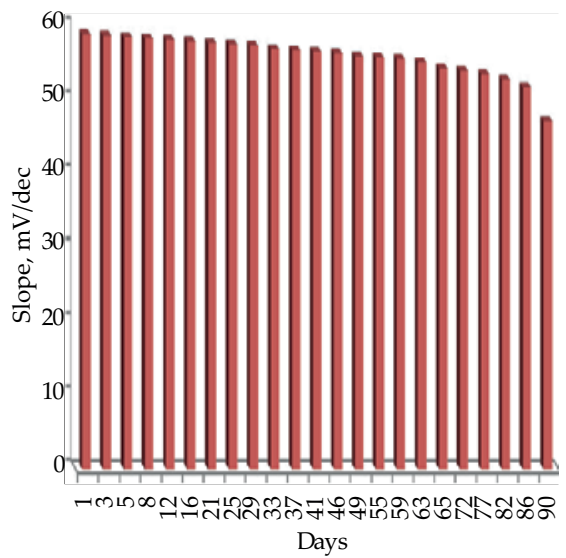

c)

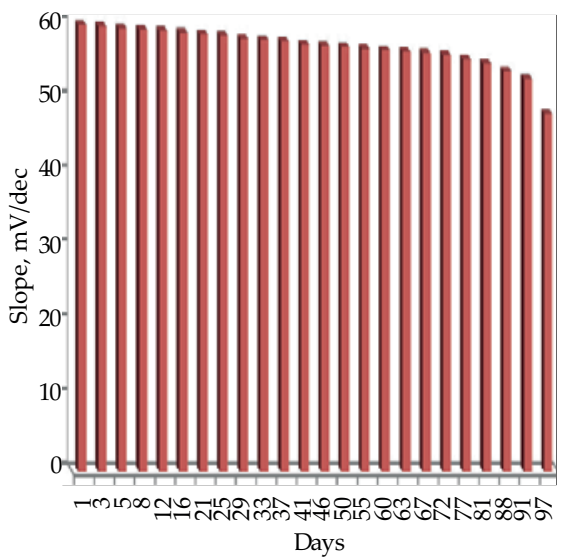

Fig. 8. Lifetime of ISPE electrodes modified with: a) $22 \mathrm{mg} \mathrm{NaTPB}$, b) $30 \mathrm{mg}$ PTA, c) $16 \mathrm{mg}$ RN ion-pairing agents

was 7.0 . The following equation was used to calculate the recovery assay at each concentration (Eq. 3):

\section{Recovery $(\%)=$}

$=[$ measured concentration/added concentration $] \cdot 100$

The potentiometric method's robustness was tested [47] by conducting the study on two different days with two different analysts (operators) and different tools. The average recovery rate for direct determinations of $400 \mu \mathrm{g} / \mathrm{ml}$ of $\mathrm{AV}-\mathrm{MOXH}$ was observed to be around $99.59 \%$ with RSD (relative standard deviation) value of 0.251 as shown in Table 7. The $\%$ RSD was $<2$ which indicated precision and accuracy of the method used [52].

\section{Limit of quantification and limit of detection. Validation of the method}

For checking the validity of this potentiometer test, the solutions were subjected to testing 5 times at different concentrations to calculate their limit of detection and quantification. At each concentration, the potentials obtained from 5 analyses were averaged. Potential and concentration have the following relationship (Eq. 4):
Logarithmic (equation 2) $\mathrm{X}=S \log [\mathrm{AV}-\mathrm{MOXH}]+\mathrm{Y}(4)$

where: $\mathrm{X}$ - potential

$S$ - slope

$\mathrm{Y}$ - intercept.

Over $\mathrm{pH}$ range of 2.0-9.0, the sensors responded linearly to concentrations ranging from $1.0 \cdot 10^{-6}$ to $1 \cdot 10^{-2} \mathrm{~mol} / \mathrm{l}$. The calculated limits of detection (LOD) and limits of quantification (LOQ) were in accordance with the IUPAC recommendation shown in Table $8[54,55]$. LOD and LOQ were 1.04 and $3.34 \mathrm{~mol} / 1$, respectively, showing good sensitivity of the suggested method.

\section{CONCLUSION}

The in-situ modified three different electrodes SPE, CPE, and PVC could be used as detectors and interesting alternative approaches for determining $\mathrm{AV}-\mathrm{MOXH}^{+}$ in various genuine samples. With minimum sample pretreatment, the manufactured electrodes showed good sensitivity, reasonable selectivity, fast static response, long-term stability, and application over a wide $\mathrm{pH}$ range of 2.0-7.0. The estimated recovery rate was around $99.59 \%$ with an RSD value of 0.251 calculated for $400 \mu \mathrm{g} / \mathrm{ml}$ of 
$\mathrm{T}$ a b 1 e 7. Potentiometric determination of AV-MOXH in pure and pharmacological preparation by calibration and SAM methods using modified ICPE, ISPE and IPVC sensors; $n$ - average of five replications $(n=5)$, SAM - Standard Addition Method, SOM Standard Official Method

\begin{tabular}{|c|c|c|c|c|c|c|c|c|c|c|c|}
\hline \multirow[b]{2}{*}{$\begin{array}{l}\text { Type of electrode } \\
\text { with modifying } \\
\text { ion-pairing agent }\end{array}$} & \multirow[b]{2}{*}{$\begin{array}{c}{[\mathrm{AV}-\mathrm{MOXH}]} \\
\mathrm{mg} / \mathrm{ml}\end{array}$} & \multicolumn{2}{|c|}{ SD, \%RSD } & \multicolumn{2}{|c|}{ Recovery rate, $\%$} & \multicolumn{2}{|c|}{$[\mathrm{AV}-\mathrm{MOXH}] \mathrm{mg} / \mathrm{ml}$} & \multicolumn{4}{|c|}{ Standard Official Method, SOM } \\
\hline & & SAM & Calibration & SAM & Calibration & Calibration & SAM & $\begin{array}{l}\% \text { RSD } \\
(n=5)\end{array}$ & $\begin{array}{l}\text { Estimated } \\
\text { recovery } \\
\text { rate, } \%\end{array}$ & $\begin{array}{c}{[\mathrm{AV}-\mathrm{MOXH}]} \\
\mathrm{mg} / \mathrm{ml}\end{array}$ & $\begin{array}{c}{[\mathrm{AV}-\mathrm{MOXH}]} \\
\mathrm{mg} / \mathrm{ml}\end{array}$ \\
\hline \multirow{2}{*}{$\begin{array}{c}\text { ICPE } \\
(10 \mathrm{mg} \text { NaTPB })\end{array}$} & 0.307 & $0.006(2.375)$ & $0.005(1.343)$ & 97.10 & 95.67 & 0.308 & 0.283 & \multirow{14}{*}{0.245} & \multirow{14}{*}{99.59} & \multirow{14}{*}{2.180} & \multirow{14}{*}{2.190} \\
\hline & 2.186 & $0.004(0.167)$ & $0.004(0.178)$ & 96.78 & 100.11 & 2.199 & 2.198 & & & & \\
\hline \multirow{2}{*}{$\begin{array}{c}\text { IPVC } \\
\text { (7.5 mg NaTPB) }\end{array}$} & 0.305 & $0.004(1.427)$ & $0.002(0.981)$ & 95.78 & 97.83 & 0.278 & 0.298 & & & & \\
\hline & 2.185 & $0.006(0.265)$ & $0.008(0.396)$ & 97.82 & 100.01 & 2.076 & 2.090 & & & & \\
\hline \multirow{2}{*}{$\begin{array}{c}\text { IPVC } \\
\text { (7.5 mg PMA) }\end{array}$} & 0.306 & $0.003(1.151)$ & $0.004(1.576)$ & 98.40 & 95.53 & 0.310 & 0.229 & & & & \\
\hline & 2.189 & $0.005(0.210)$ & $0.007(0.335)$ & 98.72 & 98.46 & 2.138 & 2.157 & & & & \\
\hline \multirow{2}{*}{$\begin{array}{c}\text { IPVC } \\
\text { (7.5 mg PTA) }\end{array}$} & 0.310 & $0.005(1.831)$ & $0.004(1.348)$ & 96.19 & 97.15 & 0.239 & 0.219 & & & & \\
\hline & 2.168 & $0.007(0.306)$ & $0.006(0.340)$ & 97.49 & 94.29 & 2.717 & 2.127 & & & & \\
\hline \multirow{2}{*}{$\begin{array}{c}\text { ISPE } \\
(16 \mathrm{mg} \mathrm{RN})\end{array}$} & 0.360 & $0.002(1.200)$ & $0.006(2.196)$ & 97.37 & 98.36 & 0.279 & 0.279 & & & & \\
\hline & 2.198 & $0.004(0.189)$ & $0.004(0.168)$ & 99.49 & 99.27 & 2.167 & 2.117 & & & & \\
\hline \multirow{2}{*}{$\begin{array}{c}\text { ISPE } \\
\text { (22 mg NaTPB) }\end{array}$} & 0.307 & 0.004 (1.907) & 0.004 (1.97) & 94.58 & 97.40 & 0.267 & 0.259 & & & & \\
\hline & 2.199 & $0.005(0.189)$ & $0.005(0.312)$ & 99.56 & 98.37 & 2.198 & 2.157 & & & & \\
\hline \multirow{2}{*}{$\begin{array}{c}\text { ISPE } \\
\text { (30 mg PTA) }\end{array}$} & 0.360 & 0.005 (1.820) & $0.006(2.059)$ & 95.07 & 97.41 & 0.279 & 0.298 & & & & \\
\hline & 2.198 & $0.005(0.282)$ & $0.004(0.221)$ & 97.04 & 98.83 & 2.138 & 2.178 & & & & \\
\hline
\end{tabular}

T a b 1 e 8. Critical response characteristics of ICPE, IPVC, and ISPE sensors

\begin{tabular}{|c|c|c|c|c|c|c|}
\hline $\begin{array}{l}\text { Type of } \\
\text { electrode }\end{array}$ & $\begin{array}{c}\text { Ion } \\
\text { modifier }\end{array}$ & $\begin{array}{l}\text { Slope } \\
\text { mV/dec }\end{array}$ & $\begin{array}{l}\mathrm{pH} \\
\text { range }\end{array}$ & $\begin{array}{c}\text { Isothermal } \\
\text { coefficient } \\
\mathrm{V} /{ }^{\circ} \mathrm{C}\end{array}$ & $\begin{array}{c}\text { Response time } \\
\mathrm{s}\end{array}$ & $\begin{array}{l}\text { Lifetime } \\
\text { days }\end{array}$ \\
\hline ICPE & 10 mg NaTPB & $58.6 \pm 1.7$ & $3.0-7.0$ & 0.269 & 7.2 & 49 \\
\hline IPVC & $7.5 \mathrm{mg}$ NaTPB & $60.0 \pm 2.0$ & $2.0-6.0$ & 0.281 & 7.5 & 16 \\
\hline IPVC & 7.5 mg PMA & $59.0 \pm 3.3$ & $2.0-6.0$ & 0.224 & 7.2 & 18 \\
\hline IPVC & $7.5 \mathrm{mg}$ PTA & $57.2 \pm 2.6$ & $2.0-6.0$ & 0.279 & 5.4 & 17 \\
\hline ISPE & $16 \mathrm{mg} \mathrm{RN}$ & $59.2 \pm 4.6$ & $2.0-6.0$ & 0.310 & 5.2 & 90 \\
\hline ISPE & 22 mg NaTPB & $57.7 \pm 2.7$ & $2.0-6.0$ & 0.271 & 5.1 & 81 \\
\hline ISPE & 30 mg PTA & $60.0 \pm 2.3$ & $2.0-6.0$ & 0.292 & 4.5 & 82 \\
\hline
\end{tabular}

AV-MOXH drug used. The given potentiometric methods for determining AV-MOXH with the described electrodes are easy, sensitive, and extremely specific, making them superior to the previously published processes for determining AV-MOXH in natural form and pharmacological composition. A standard AV-MOXH stock solution was used to achieve validation characteristics including reliability, accuracy, uniformity, sensitivity, and limit of detection (LOD) and quantification (LOQ). The suggested potentiometric method's high accuracy and precision are indicated by low standard deviation and relative standard deviation values. Table 8 shows the critical response received from the above investigations. The sensors were employed as indicator electrodes for AVELOX-Moxifloxacin HCL potentiometric titration. The findings obtained are comparable to the HPLC official method in terms of the agreement. Thus, we can conclude that the suggested sensors are to be effective for the direct determination of the strength of AVELOX-Moxifloxacin HCL in the field of medical and pharmacological measures and hence can be effectively used as an antibiotic drug.

\section{REFERENCES:}

[1] Abdelaziz A.A., Elbanna T.E., Gamaleldeen N.M.: Brazilian Journal of Microbiology 2012, 43, 1291. https://doi.org/10.1590/S1517-83822012000400008

[2] Avelox - Uses, Side Effects, and More: https://www. webmd.com/drugs/2/drug-17879/avelox-oral/details (access date: 16.12.2021)

[3] Hubicka U., Żuromska-Witek B., Krzek J. et al.: Acta Poloniae Pharmaceutica - Drug Research 2012, 69, 821. 
[4] Al Omari M.M.H., Jaafari D.S., Al-Sou'od K.A. et al.: Profiles of Drug Substances, Excipients and Related Methodology 2014, 39, 299. https://doi.org/10.1016/B978-0-12-800173-8.00007-6

[5] Naidoo A., Naidoo K., McIlleron H. et al.: The Journal of Clinical Pharmacology 2017, 57, 1369. https://doi.org/10.1002/jcph.968

[6] Li S.-Z., Plésiat P., Nikaido H.: Clinical Microbiology Reviews 2015, 28, 337. https://doi.org/10.1128/CMR.00117-14

[7] Avelox: https://www.rxlist.com/avelox-drug.htm (access date: 16.12.2021)

[8] Guerra F.L., Paim C.S., Steppe M. et al.: Journal of AOAC International 2005, 88, 1086. https://doi.org/10.1093/jaoac/88.4.1086

[9] Motwani S.K., Chopra S., Ahmad F.J. et al.: Spectrochimica Acta Part A: Molecular and Biomolecular Spectroscopy 2007, 68, 250. https://doi.org/10.1016/j.saa.2006.11.023

[10] Elbashir A.A., Ebraheem S.A., Elwagee A.H. et al.: Acta Chimica Slovenica 2013, 60, 159.

[11] Kamruzzaman M., Alam A.-M., Lee S.H. et al.: Spectrochimica Acta Part A: Molecular and Biomolecular Spectroscopy 2012, 86, 375. https://doi.org/10.1016/j.saa.2011.10.051

[12] Trindade M.A.G., da Silva G.M., Ferreira V.S.: Microchemical Journal, 2005, 81, 209. https://doi.org/10.1016/j.microc.2005.06.002

[13] Al-Ghannam S.M.: Spectrochimica Acta Part A: Molecular and Biomolecular Spectroscopy 2008, 69, 1188. https://doi.org/10.1016/j.saa.2007.06.023

[14] Radi A.E., Wahdan T., Anwar Z. et al.: Drug Testing and Analysis 2010, 2, 397. https://doi.org/10.1002/dta.143

[15] Xu Y.H., Li D., Liu X.Y. et al.: Journal of Chromatography B: Analytical Technologies in the Biomedical and Life Sciences 2010, 878, 3437. https://doi.org/10.1016/j.jchromb.2010.10.024

[16] Alhaj Sakur A., Bassmajei M.S., Dabbeet H.A.: International Journal of Academic Scientific Research 2015, 3 (4), 66.

[17] Momin M.A.M., Rangnekar B., Das S.C.: Journal of Liquid Chromatography \& Related Technologies 2018, 41, 415. https://doi.org/10.1080/10826076.2018.1437748

[18] Czyrski A., Sokół A., Szałek E.: Journal of Liquid Chromatography \& Related Technologies 2017, 40, 8. https://doi.org/10.1080/10826076.2017.1280680

[19] Wichitnithad W., Kiatkumjorn T., Jithavech P. et al.: Die Pharmazie 2018, 73, 625. https://doi.org/10.1691/ph.2018.8148

[20] Khan F.U., Nasir F., Iqbal Z. et al.: Journal of Chromatography B: Analytical Technologies in the Biomedical and Life Sciences 2016, 1017-1018, 120. https://doi.org/10.1016/j.jchromb.2016.03.002

[21] Cruz L.A., Hall R.: Journal of Pharmaceutical and Biomedical Analysis 2005, 38, 8. https://doi.org/10.1016/j.jpba.2004.12.004
[22] Raju B., Ramesh M., Borkar R.M. et al.: Biomedical Chromatography 2012, 26, 1341. https://doi.org/10.1002/bmc.2701

[23] Nguyen D.T.T., Guillarme D., Rudaz S. et al.: Journal of Separation Science 2008, 31, 1050. https://doi.org/10.1002/jssc.200700537

[24] Pranger A.D., Alffenaar J.W.C., Mireille A. et al.: Journal of Analytical Toxicology 2010, 34, 135. https://doi.org/10.1093/jat/34.3.135

[25] Vu D.H., Koster R.A., Alffenaar J.W.C.: Journal of Chromatography B: Analytical Technologies in the Biomedical and Life Sciences 2011, 879, 1063. https://doi.org/10.1016/j.jchromb.2011.03.017

[26] Cruz L.A., Hall R.: Journal of Pharmaceutical and Biomedical Analysis 2005, 38, 8. https://doi.org/10.1016/j.jpba.2004.12.004

[27] Attimarad M., Chohan M.S., Balgoname A.A.: International Journal of Environmental Research and Public Health 2019, 16, 1196. https://doi.org/10.3390/ijerph16071196

[28] David Harvey, Potentiometric methods: chem.libretexts.org/Courses/Northeastern_University/11\%3A Electrochemical_Methods/11.2\%3A_Potentiometric_ Methods (access date: 16.12.2021)

[29] Hefnawy M.M., Homoda A.M., Abounassif M.A. et al:: Chemistry Central Journal 2014, 8, 59. https://doi.org/10.1186/s13065-014-0059-y

[30] Tymecki L., Glab S., Koncki R.: Sensors 2006, 6, 390. https://doi.org/10.3390/s6040390

[31] Honeychurch K.C., Hart J.P.: TrAC Trends in Analytical Chemistry 2003, 22, 456. https://doi.org/10.1016/S0165-9936(03)00703-9

[32] Schöning M.J., Simonis A., Krings T. et al.: Electroanalysis 2002, 14, 955.

h t t p s://d o i.org / $10.1002 / 1521$ -4109(200207)14:13<955::AID-ELAN955>3.0.CO;2-\%23

[33] Frag E.Y.Z., Mohamed G.G., El-Dien F.A.N. et al.: Analyst 2011, 136, 332. https://doi.org/10.1039/C0AN00343C

[34] Khaled E., Mohamed G.G., Awad T.: Sensors and Actuators B: Chemical 2008, 135, 74. https://doi.org/10.1016/j.snb.2008.07.027

[35] Svancara L., Vytras K.: Chemické Listy 1994, 88, 138.

[36] Bakker E., Pretsch E., Bühlmann P.: Analytical Chemistry 2000, 72, 1127. https://doi.org/10.1021/Ac991146N

[37] Hsissou R., Seghiri R., Benzekri Z. et al.: Composite Structures 2021, 262, 113640. https://doi.org/10.1016/j.compstruct.2021.113640

[38] Marturano V., Cerruti P., Ambrogi V.: Physical Sciences Reviews 2017, 2, 20160130. https://doi.org/10.1515/psr-2016-0130

[39] Maksymiuk K., Stelmach E., Michalska A.: Membranes 2020, 10, 266. https://doi.org/10.3390/membranes10100266

[40] Alrabiah H., Al-Majed A., Abounassif M. et al.: Acta Pharmaceutica 2016, 66, 503. 
https://doi.org/10.1515/acph-2016-0042

[41] Rippeth J.J., Gibson T.D., Hart J.P. et al.: Analyst 1997, 122, 1425.

https://doi.org/10.1039/A704291D

[42] Buck R.P., Lindner E.: Pure and Applied Chemistry 1994, 66, 2527.

https://doi.org/10.1351/pac199466122527

[43] Umezawa Y., Umezawa K., Sato H.: Pure and Applied Chemistry 1995, 67, 507.

https://doi.org/10.1351/pac199567030507

[44] Egorov V.V., Zdrachek E.A., Nazarov V.A.: Analytical Chemistry 2014, 86, 3693. https://doi.org/10.1021/ac500439m

[45] Ghoreishi S.M., Behpour M.,, Nabi M.: Sensors and Actuators B: Chemical 2006, 113, 963. https://doi.org/10.1016/j.snb.2005.04.003

[46] Othman A.M., Rizk N.M.H., El-Shahawi M.S.: Analytica Chimica Acta 2004, 515, 303. https://doi.org/10.1016/j.aca.2004.01.016

[47] Miller J.C., Miller J.N.: "Statistics for Analytical Chemistry", $1^{\text {st }}$ edition, England: Ellis Harwood Limited, 1986.

[48] Ganjali M.R., Memari Z., Faridbod F. et al.: International Journal of Electrochemical Science 2008, 3, 1169. http://www.electrochemsci.org/papers/vol3/3101169. pdf

[49] Gupta V.K., Chandra S., Mangla R.: Sensors and Actuators B: Chemical 2002, 86, 235.

https://doi.org/10.1016/S0925-4005(02)00193-4

[50] Gupta V.K., Prasad R., Kumar A.: Talanta 2004, 63, 1027.

https://doi.org/10.1016/j.talanta.2004.01.012

[51] Zamani H.A., Rajabzadeh G., Ganjali M.R.: Sensors and Actuators B: Chemical 2006, 119, 41. https://doi.org/10.1016/j.snb.2005.11.048

[52] Ashour S., Kattan N.: SOJ Pharmacy \& Pharmaceutical Sciences 2016, 3, 1. https://doi.org/10.15226/2374-6866/3/3/00145

[53] Long G.L., Winefordner J.D.: Analytical Chemistry 1983, 55, 712A. https://doi.org/10.1021/ac00258a724

[54] Jain A.K., Gupta V.K., Singh L.P. et al.: Electrochimica Acta 2006, 51, 2547. https://doi.org/10.1016/j.electacta.2005.07.040

[55] Ma T.S., Hassan S.M.M.: “Organic Analysis Using Ion Selective Electrodes", vol. 1\&2, Academic Press, London, 1982.

Received 4 XI 2021.

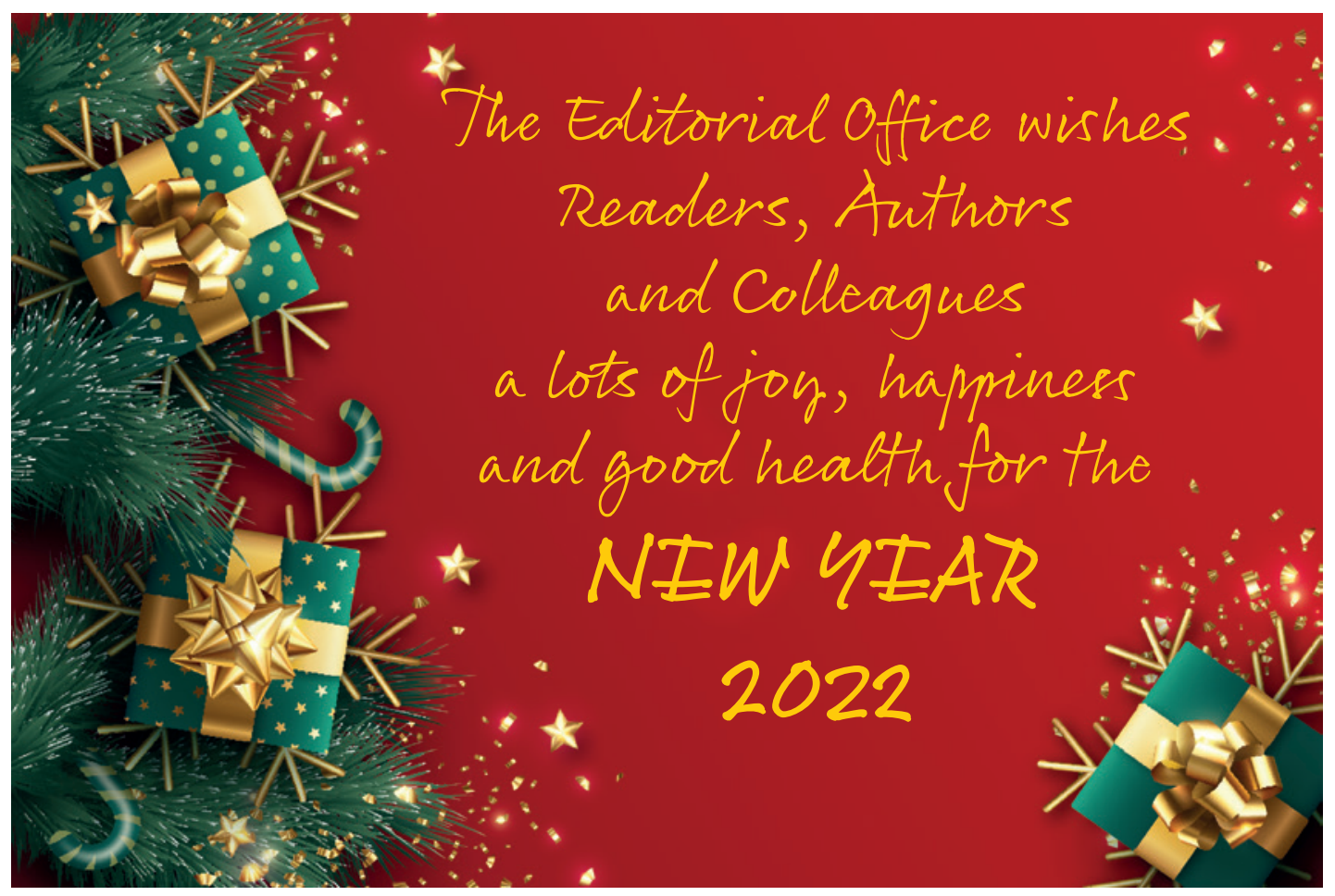

